\title{
Developmental dysfluency: early intervention is key
}

Background and epidemiology: Speech is a remarkable and complicated achievement involving a variety of linguistic, cognitive and sensorimotor processes. Little wonder that about $85 \%$ of children between the ages of 2 and 6 encounter a few bumps and breaks along the path to fluent speech. ${ }^{1}$ Preschool children normally go through a period of dysfluency; about $10 \%$ of preschoolers experience a speech or language delay or disorder serious enough to benefit from early referral and assessment by a speechlanguage pathologist (SLP). The etiology and mechanisms of developmental speech dysfluency are complicated and a matter of some debate. In general, it signals a lack of coordination between linguistic intention and motor articulation as children learn to talk and think at the same time.

Common examples of developmental dysfluency include repetitions, interjections, pauses, revisions and mistiming (Box 1). Children may repeat individual $\approx$ sounds or syllables, especially at the beginning of words. Interjections are extra sounds, syllables or words that add no meaning to the message. Pauses or blocking (silent intervals between or within words), may be considered a type of dysfluency,

\section{Box 2: Indications for referral to a speech-language pathologist $^{2}$}

- Three or more stuttering-like dysfluencies (e.g., "b-but," "thi-thi-this," "you you you," "and and," "mummy," "cookie," "...toy," "O...pen") per 100 syllables uttered

- The child exhibits reactions of avoidance or escape (e.g., pauses, interjections ["uh," "uhm"], eye blinks, head nods)

- The child appears tense and uncomfortable

- The general practitioner is in doubt as to the nature of the child's speech changes

especially when they last more than 2 seconds. Revision refers to the habit of stopping in midstream and starting over in a new direction. Mistiming refers to the prolongation of sounds or syllables.'

Most children outgrow the period of dysfluency, but those who do not will require speech therapy, so it is important that a distinction be made between childhood dysfluency and stuttering. Stuttering is a disturbance in the normal fluency and time patterning of speech that is inappropriate for the person's age. We all experience periods of dysfluency - normal speech includes $2 \%-4 \%$ interruptions in flow or fluency. Generally speaking, revisions, interjections and word and phrase repetitions are very common in children's speech; sound and syllable repe-

\begin{tabular}{|c|c|}
\hline Behaviour & Example \\
\hline Repetition & $\begin{array}{l}\text { The baby ate the s-soup. } \\
\text { The ba-ba-baby ate the soup. } \\
\text { The-the baby ate the soup. }\end{array}$ \\
\hline $\begin{array}{l}\text { Interjection, } \\
\text { fillers }\end{array}$ & $\begin{array}{l}\text { The uh baby ate the soup. } \\
\text { The baby um ate the soup }\end{array}$ \\
\hline Pauses, blocks & $\begin{array}{l}\text { The ba-[pause] by ate the soup. } \\
\text { The baby ate the [pause] soup. }\end{array}$ \\
\hline Revision & $\begin{array}{l}\text { The baby ate - eated the soup. } \\
\text { The daddy - The baby ate the soup. }\end{array}$ \\
\hline $\begin{array}{l}\text { Mistiming, } \\
\text { prolonation }\end{array}$ & $\begin{array}{l}\text { The baaaby ate the soup. } \\
\text { The baby ate the ssssoup. }\end{array}$ \\
\hline
\end{tabular}

tition, sound prolongation and broken words are more atypical.

Speech patterns and behaviours that might signal that a child is at risk of stuttering include within-word or part-word repetitions, prolonged sounds, avoiding speaking situations or saying "I can't say it," looking upset, speaking with tension in the face or neck muscles or voice and speaking with unexpected rises in pitch or loudness. ${ }^{1}$ Boys are 4 times more likely than girls to develop a stutter. Children with a family history of stuttering are more likely to stutter than children without.

Clinical management: In general, primary care physicians can reassure parents that transient speech dysfluency is normal in preschoolers. However, they also need to be aware of the indications for referral of children to an $\mathrm{SLP}^{2}$ (Box 2). Parents know their child the best, so lingering parental concern may be reason enough to refer the child for speech and language assessment. A physician referral to an SLP is not usually required in most provinces, but physicians can refer with a parent's consent.

The SLP evaluates the child and then makes appropriate recommendations based on each child and their family according to factors such as severity of disorder, type and frequency of dysfluencies, parental commitment and concomitant developmental 
delays. For preschool fluency, the first therapeutic step usually involves training the parent to facilitate a more fluent speech environment in day-to-day interactions. The SLP may also provide a home program or monitor the child's progress regularly. Therapy could occur in a parent education group or in a group with several children and families.
SLPs must complete a minimum of a master's degree in Speech-Language Pathology in order to practise in Canada. These specialists are in short supply and high demand, so early referral is optimal. In general, preschool and school-based speech and language services are government-funded. Most private insurance plans will offer

\title{
Box 3: Ways to reduce conversational demands on the child
}

\section{Advice}

Use a slower rate of speech and insert pauses in your speech

Decrease questions

Listen carefully

Do not interrupt

Acknowledge when speech is difficult

Create a special talk time

\section{Rationale or example}

By speaking slowly, you provide a good model for your child. Pausing allows the child to continue to speak

Questions put pressure on the child to respond

What the child is saying (not how) is the most important thing at that moment.

Be patient. Do not look away when the child is dysfluent - it signals your discomfort.

"That was a hard word. I have trouble saying upholstery too." Use this time to practise your slow rate with the child. some coverage, under rehabilitative services.

Prevention: The etiology of stuttering is not completely understood. Adults can mitigate the risk of stuttering by reducing the conversational demands on a child — that is, by assuming a "Mr. Rogers" approach to conversation by modeling slow, smooth speech, acknowledging when speech is difficult and creating special talk time (Box 3 ).

\section{Erica Weir}

Associate Medical Officer of Health Sonya Bianchet

Speech-Language Pathologist

Early Expressions Speech and

Language Services

Kingston, Frontenac and Lennox \&

Addington Health Unit

Kingston, Ont.

\section{References}

1. Schrader M, editor. Parent articles 1: Enhance parent involvement in language learning. Arizona: Communication Skill Builders; 1996.

2. Costa D, Kroll R. Stuttering: an update for physicians. CMA7 2000;162 (13):1849-55.

For more information consult the Canadian Association of SpeechLanguage Pathologists and Audiologists: www.caslpa.ca.

\section{How you can get involved in the CMA!}

The CMA is committed to providing leadership for physicians and promoting the highest standard of health and health care for Canadians. To strengthen the Association and be truly representative of all Canadian physicians, the CMA needs to hear from members interested in serving in elected positions and on appointed committees and advisory groups.

The CMA structure comprises both governing bodies and advisory bodies either elected by General Council or appointed by the CMA Board of Directors. The Board of Directors - elected by General Council — has divisional, affiliate, resident and student representation, is responsible for the overall operation of the CMA and reports to General Council on issues of governance. CMA councils and committees advise the Board of Directors and make recommendations on specific issues of concern to physicians and the public. Four core councils and committees consist of either divisional or regional representation, while other statutory and special committees, and expert working and project advisory groups comprise individuals with interest and expertise in subject-specific fields. Positions on one or more of these committees may become available in the coming year.

For further information on how you can get involved, please contact:

\author{
Prunella Hickson \\ Corporate Affairs \\ Canadian Medical Association \\ 1867 Alta Vista Drive \\ Ottawa ON K1G 3 Y6 \\ Fax 613 526-7570 \\ Tel $1800663-7336$, x2249 \\ Email prunella.hickson@cma.ca
}

By getting involved, you will have an opportunity to make a difference.

We hope to hear from you! 